Original Research Article

\title{
Evaluation of the antipeptic ulcer activity of the seed extract of sesame (Sesamum indicum) in stress induced peptic ulcers in rats
}

\author{
Ravi K. Sori' ${ }^{1}$, Balaji O. ${ }^{2}$, Shalini Adiga ${ }^{3 *}$, Huban Thomas ${ }^{2}$
}

${ }^{1}$ Department of Pharmacology, SDM College of Medical

Sciences \& Hospital, Dharward, Karnataka, India

${ }^{2}$ Department of Pharmacology,

${ }^{3}$ Department of Anatomy,

Kasturba Medical College,

Manipal, Karnataka, India

Received: 22 February 2018

Revised: 14 April 2018

Accepted: 25 April 2018

*Correspondence to:

Dr. Shalini Adiga,

Email: soriravi@gmail.com

Copyright: (C) the author(s), publisher and licensee Medip Academy. This is an openaccess article distributed under the terms of the Creative Commons Attribution NonCommercial License, which permits unrestricted noncommercial use, distribution, and reproduction in any medium, provided the original work is properly cited.

\begin{abstract}
Background: The peptic ulcers can be developed inside the inner lining of the stomach (gastric ulcer) or the small intestine (duodenal ulcer). Around 10\% population of the world is suffering from the peptic ulcer disease. From the ancient times there is a reference about herbal extracts like Sesame indicum for the treatment of various diseases. The aim of the study is Evaluation of the antipeptic ulcer activity of the seed extract of sesame (Sesamum indicum) in stress induced peptic ulcers in rats.

Methods: The study was carried out by stress-induced ulcer model in wistar rats. The antiulcer activity of $S$. indicum $(0.5,1 \mathrm{mg} / \mathrm{kg}$ p.o. for 7 days) was compared with standard drugs (pantoprazole). The studied parameters were mucin content, gastric volume, $\mathrm{pH}$, total acidity, free acidity, ulcer index, size and number.

Results: The low and high dose of $S$. indicum extract significantly reduced gastric mucosal lesion, mucin content, volume of gastric juice, gastric $\mathrm{pH}$, free and total acidity when compared to positive control group. The high dose of $S$. indicum extract showed comparable results in parameters like effect on mucin content, gastric volume, $\mathrm{pH}$, free acidity and total acidity with standard group. The statistical significant changes noted only in ulcer size, number and index.

Conclusions: Although the high dose $S$. indicum $(1 \mathrm{mg} / \mathrm{kg})$ group showed significant gastric protection against ulcer induced by cold restraint method. However, no clear inference can be drawn at this stage and hence there is a need for further extensive research.
\end{abstract}

Keywords: Anti-peptic ulcer effect, Gastric ulcer, Sesamum indicum

\section{INTRODUCTION}

Peptic ulcer diseases are a group of heterogeneous disorders, which manifests as a break in the lining of gastrointestinal mucosa bathed by pepsin and acid. Among the diseases of gastro-intestinal diseases, peptic ulcer is the most predominant with a worldwide prevalence of about $40 \%$ in the developed countries and $80 \%$ in the developing countries. The pathology of the gastric ulcer is lack of equilibrium between gastric aggressive factors and the mucosal defensive factors. ${ }^{1}$ The present modality of treatment is the use of histamine $\mathrm{H} 2$ - receptor antagonists, anticholinergic drugs, antacids and PPI's. From olden days, there have been use of plant sources in the treatment of various disease modalities due to their perceived lower side effects, ease of accessibility and affordability. Plants are some of the most attractive sources for the discovery of new drugs and some have been shown to have promise for the treatment of gastro duodenal ulcer with minimum side effects. ${ }^{1}$ Plants with traditional ethno medicinal uses in peptic ulcer management thus need to be screened for potential antiulcer activity. The sesame oil contain the lignans, sesamolin, sesamin, pinoresinol and lariciresinol. Sesamol (SES), is a component of traditional health food in various Asian countries. It protects against atherosclerosis, hypertension, and aging. It has also been 
explored for wound healing, antioxidant, antiinflammatory, and free radical scavenging activity. ${ }^{2}$

Presently there are very less studies done on anti-peptic ulcer activity of Sesame oil. Therefore, the aim of the present study is to evaluate the anti-peptic ulcer activity of the seed extract of Sesame (Sesamum indicum) in stress induced peptic ulcers in wistar rats.

\section{METHODS}

The study is conducted after the approval issued by Institutional Animal Ethics Committee (IAEC/KMC/13/2016).

\section{Chemicals/drugs/ instruments used}

Pantoprazole, S. indicum seed extract, ketamine, orcinol $1.6 \%$, sulphuric acid $60 \%$, phenolphthalein, topfer's reagent, $0.5 \%$ carboxymethyl Cellulose, distilled water, surgical kit, $\mathrm{pH}$ meter.

\section{Plant preparation and extraction}

The fresh sesame seeds were purchased from the local market and seeds were grinded to fine powder. The powder is filled in to filter paper bag and placed ilaced in the soxhlet apparatus for extraction. The soxhlet apparatus is connected to round bottom flask which is fill by ethanol $(90 \%)$ solvent and water bath to maintain temperature. The ethanol was boiled at $40{ }^{\circ} \mathrm{C}$ for over a period of 24 hours. The extract obtained was $10 \%$ and was stored in desiccator at room temperature.

\section{Experimental animals}

The animals were taken from central animal house male/female albino rats of Wistar strain, weight - 200$250 \mathrm{gm}$. The animals were housed under standard condition, housed individually with normal water and food granules, 12:12 hours light dark cycle, 50\% humidity and $28^{\circ} \mathrm{C}$ temperature and provided with standard food granules and water ad libitum.

\section{Animal grouping and treatment}

\section{Ulcer inducing method}

The procedure for inducing ulcers is with the stressinduced ulcer model, which include animals being fasted for a period of 18-24 hours prior to the experiment. Ulcers are then induced by placing animals individually in a restricted cage for 8 hours and in restraint cold ventilated refrigerator at a temperature of $2-3^{\circ} \mathrm{C}$ for $2-4$ hours. ${ }^{1}$

\section{Drug dosing}

- $\quad$ Group I - Negative control, 0.9\% normal saline - no ulcers induced $\mathrm{x} 7$ days
- Group II - Positive control 0.9\% saline + ulcer induced rats $\mathrm{x} 7$ days

- $\quad$ Group III - Standard - pantoprazole $30 \mathrm{mg} / \mathrm{kg}$ x 7 days

- $\quad$ Group IV - Test 1 - sesame extract $0.5 \mathrm{mg} / \mathrm{kg}$ x 7 days

- Group V - Test 2 - sesame extract $1 \mathrm{mg} / \mathrm{kg}$ x 7 days

Day 1 - The ulcers were induced by the Stress-Induced Ulcer Model. From Day 3 - 9: Standard and test drugs are given via oral route via a feeding tube and animals are dosed once a day, with $0.5 \%$ carboxy methyl Cellulose (vehicle) for 7days, with the dosage mentioned above. On day 10 - the animals are euthanized using ketamine, the abdomen is dissected then the stomach was removed for the assessment of gastric mucosal damage.

Table 1: Animals were divided in to 5 treatment groups 6 rats in each group.

\begin{tabular}{|c|c|c|c|}
\hline $\begin{array}{l}\text { Group } \\
\text { no. }\end{array}$ & $\begin{array}{l}\text { Group } \\
\text { name }\end{array}$ & $\begin{array}{l}\text { Drugs to be } \\
\text { administered }\end{array}$ & $\begin{array}{l}\text { No. of } \\
\text { rats }\end{array}$ \\
\hline I & $\begin{array}{l}\text { Negative } \\
\text { Control }\end{array}$ & $0.9 \%$ Normal saline & 6 \\
\hline II & $\begin{array}{l}\text { Positive } \\
\text { Control }\end{array}$ & $\begin{array}{l}0.9 \% \text { Normal saline }+ \\
\text { ulcer induced rats }\end{array}$ & 6 \\
\hline III & Standard & Pantoprazole $(30 \mathrm{mg} / \mathrm{kg})$ & 6 \\
\hline IV & $\begin{array}{l}\text { Test } \\
\text { dose } 1\end{array}$ & $\begin{array}{l}\text { S. indicum extract } \\
(0.5 \mathrm{mg} / \mathrm{kg}) \text { for } 7 \text { days }\end{array}$ & 6 \\
\hline \multirow[t]{2}{*}{ V } & $\begin{array}{l}\text { Test } \\
\text { dose } 2\end{array}$ & $\begin{array}{l}\text { S. indicum extract } \\
(1 \mathrm{mg} / \mathrm{kg}) \text { for } 7 \text { days }\end{array}$ & 6 \\
\hline & & Total rats & 30 \\
\hline
\end{tabular}

All drugs are given via oral route via a feeding tube and animals are dosed once a day, with $0.5 \%$ carboxy methyl Cellulose (vehicle)

\section{Measurement of ulcer}

The stomach was dissected along the greater curvature and fixing on a board or transparent glass examination can be carried out with hand lens macroscopically and by a tracing on the transparent paper and the paper on to graph sheets and size of ulcers and the ulcer index was calculated as per the method of Rao et al. ${ }^{3}$

Ulcer index $=$ Ulcer size $\mathrm{X}$ ulcer number

\section{Mucin content determination: (Winzler method)}

Diluted sample orcinol (1.6\%) and sulphuric acid (60\%) are added, vortexed and boiled for $10 \mathrm{~min}$ mixtures are cooled in ice-cooled water to stop reaction and absorbance studied at $425 \mathrm{~nm}$.

\section{Measurement of volume of gastric juice}

Gastric juice from the stomach will be drained into a centrifuge tube after the animals were sacrificed. The tube will be centrifuged at 3000 rpm for 10 minutes and the Centrifuged sample will be decanted and analysed for the volume of gastric juice. ${ }^{3}$ 


\section{Measurement of pH of gastric juice}

$\mathrm{pH}$ of the centrifuged sample of gastric juice is measured using a digital pH Meter, type DPH-100 (Dalal instruments).

\section{Measurement of free and total acidity}

The free and total acidity is measured by titrating $0.1 \mathrm{ml}$ of gastric juice with $0.01 \mathrm{NaOH}$ using topfers reagent and phenolphthalein as INDICATORS (HAWK, 1965). Orange yellow and point with topfers reagent Is for the free acid content and the pink endpoint with phenolphthalein gives a measure of total acid content. Acidity is expressed as $\mathrm{mEq} / \mathrm{L}$ per 100 grams body weight.

\section{Statistical analysis}

The results will be analyzed using one way ANOVA in SPSS 21 Software for Microsoft. The statistical significant value for any measure was set to $\mathrm{p}<0.05$ at a confidence interval of $95 \%$. The results expressed are in mean \pm standard error mean.

\section{RESULTS}

The high dose of $S$. indicum extracts (group-5) significantly reduced gastric mucosal lesion (Table 2), mucin content (Table 3), volume of gastric juice (Table 3), gastric $\mathrm{pH}$ (Table 3 ), free and total acidity (group-3) when compared to positive control group.

Table 2: Effect of $S$. indicum on gastric ulcer.

\begin{tabular}{|llll|}
\hline Group & $\begin{array}{l}\text { Mean ulcer } \\
\text { Size }(\mathrm{mm})\end{array}$ & $\begin{array}{l}\text { Mean ulcer } \\
\text { number }\end{array}$ & $\begin{array}{l}\text { Mean ulcer } \\
\text { index }\end{array}$ \\
\hline Group I & - & - & - \\
\hline Group II & $23.8 \pm 0.47^{\mathrm{c}-\mathrm{e}}$ & $12.5 \pm 0.76^{\mathrm{c}-\mathrm{e}}$ & $298 \pm 19.5^{\mathrm{c}-\mathrm{e}}$ \\
\hline Group III & $1.4 \pm 0.3^{\mathrm{b}, \mathrm{d}}$ & $2 \pm 0.4^{\mathrm{b}, \mathrm{d}}$ & $3.15 \pm 0.6^{\mathrm{b}, \mathrm{d}}$ \\
\hline Group IV & $10.4 \pm 0.4^{\mathrm{b}, \mathrm{c}, \mathrm{e}}$ & $9.5 \pm 0.4^{\mathrm{b}, \mathrm{c}, \mathrm{e}}$ & $101.3 \pm 0.7^{\mathrm{b}, \mathrm{e}, \mathrm{e}}$ \\
\hline Group V & $1.6 \pm 0.3^{\mathrm{b}, \mathrm{d}}$ & $2.8 \pm 0.65^{\mathrm{b}, \mathrm{d}}$ & $5.4 \pm 1.4^{\mathrm{b}, \mathrm{d}}$ \\
\hline
\end{tabular}

Values are mean \pm SEM $(n=6)$. Values are statistically significant at $* \mathrm{P}<0.05$ using one way ANOVA followed by Tukey's test. b: $\mathrm{p}<0.05$ vs positive control, c: $\mathrm{p}<0.005$ vs standard, $\mathrm{d}$ : $\mathrm{p}<0.05$ vs test 1 , e: $\mathrm{p}<0.05$ vs test 2

The low dose test group (group-4) showed significantly reduced gastric mucosal lesion (Table 2), mucin content (Table 3), volume of gastric juice (Table 3), gastric $\mathrm{pH}$ (Table 3), free and total acidity (group-3) when compared to positive control group. When compared with the standard group it showed significant changes only in ulcer size, number and index but not in other laboratory parameters.
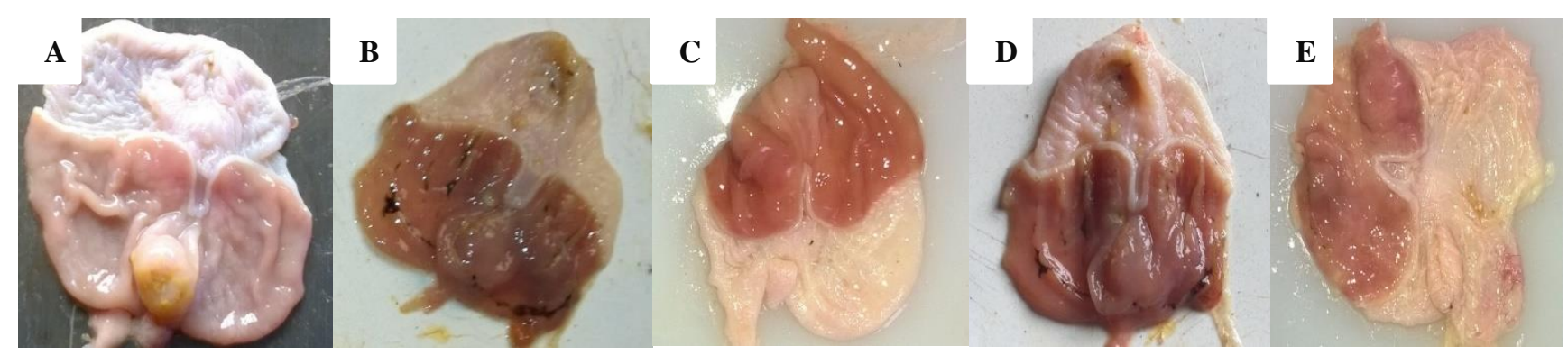

Figure 1 (A to E): Dissected part of the stomach on day $10^{\text {th }}$ showing ulcers in each treatment group. A) Negative control group, B) Positive control group, C) Standard group, D) Test 1 group, E) Test 2 group.

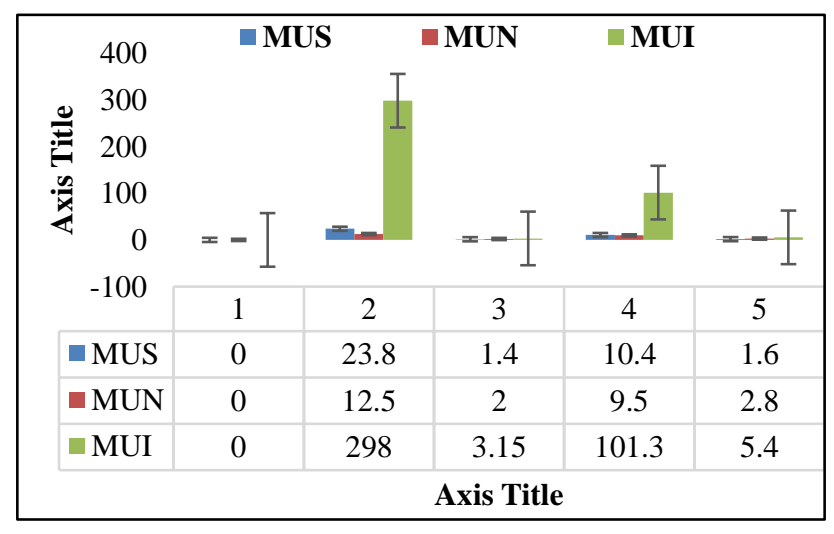

Figure 2: Mean ulcer- size/ number/ index.

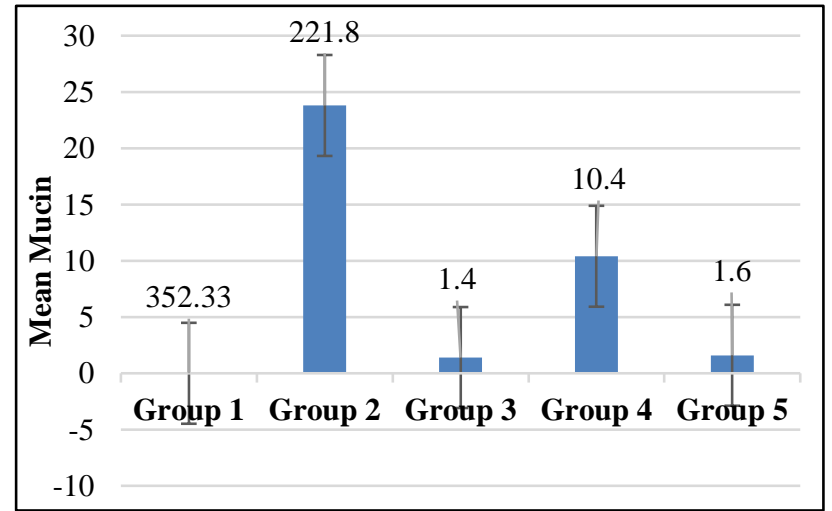

Figure 3: Mean mucin content. 
Table 3: Effect of $S$. indicum on Mucin Content, pH and Vol. of Gastric Juice

\begin{tabular}{|c|c|c|c|}
\hline Group & Mucin & pH & $\begin{array}{l}\text { Volume of } \\
\text { gastric juice } \\
\text { (ml) }\end{array}$ \\
\hline Group I & $352.33 \pm 3.8^{\mathrm{b}-\mathrm{e}}$ & $4.49 \pm .04^{\mathrm{b}}$ & $2.02 \pm 0.07^{b-e}$ \\
\hline Group II & $221.8 \pm 1.7^{\mathrm{c}-\mathrm{e}}$ & $2.56 \pm 0.03^{\mathrm{c}-\mathrm{e}}$ & $7.27 \pm 0.12^{\mathrm{a}, \mathrm{c}-\mathrm{e}}$ \\
\hline Group III & $331.1 \pm 3.7^{b}$ & $4.56 \pm 0.73^{b}$ & $3.07 \pm 0.07^{\mathrm{a}, \mathrm{b}}$ \\
\hline Group IV & $340.5 \pm 2.1^{\mathrm{b}}$ & $4.6 \pm 0.06^{\mathrm{b}}$ & $3.7 \pm 0.10^{\mathrm{a}, \mathrm{b}}$ \\
\hline Group V & $315 \pm 8.8^{\mathrm{b}}$ & $4.1 \pm 0.16^{b}$ & $4.2 \pm 0.29^{\mathrm{a}, \mathrm{b}}$ \\
\hline
\end{tabular}

The high dose of $S$. indicum extract (group-5) showed comparable results in parameters like effect on mucin content, gastric volume, $\mathrm{pH}$, free acidity and total acidity with the standard group (Table 3, 4 and 5). The statistical significant changes noted only in ulcer size, number and index (Table 2).

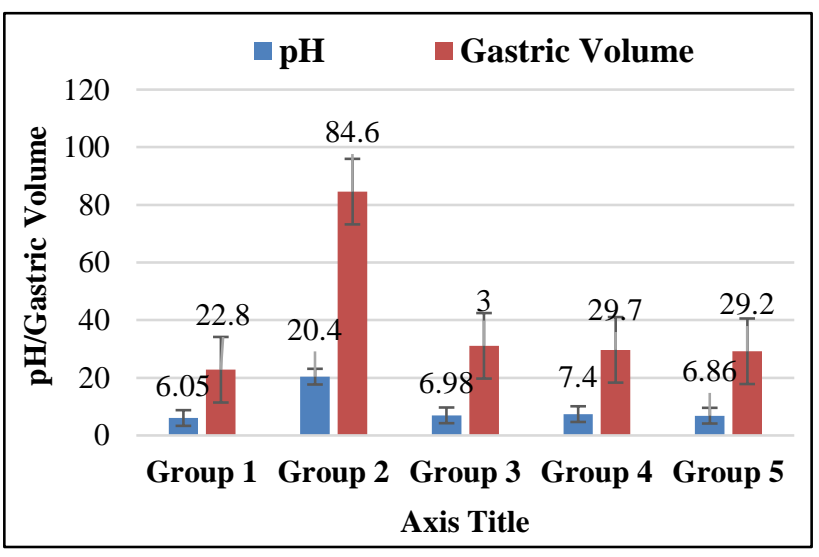

Figure 4: Mean pH and gastric volume.

Table 4: Effect of $S$. indicum on free acidity and total acidity.

\begin{tabular}{|lll|} 
Group & $\begin{array}{l}\text { Free acidity } \\
(\mathrm{mEq} /\end{array}$ & $\begin{array}{l}\text { Total acidity } \\
\text { L/HEq/100gm) }\end{array}$ \\
\hline Group I & $6.05 \pm 0.05^{\mathrm{b}-\mathrm{e}}$ & $22.8 \pm 1.4^{\mathrm{b}-\mathrm{e}}$ \\
\hline Group II & $20.4 \pm 0.09^{\mathrm{c}-\mathrm{e}}$ & $84.6 \pm 0.37^{\mathrm{c}-\mathrm{e}}$ \\
\hline Group III & $6.98 \pm 0.08^{\mathrm{a}, \mathrm{b}, \mathrm{d}}$ & $31.1 \pm 0.37^{\mathrm{a}, \mathrm{b}}$ \\
\hline Group IV & $7.4 \pm 0.13^{\mathrm{a}, \mathrm{b}, \mathrm{c}, \mathrm{e}}$ & $29.7 \pm 0.54^{\mathrm{a}, \mathrm{b}}$ \\
\hline Group V & $6.86 \pm 0.08^{\mathrm{a}, \mathrm{b}, \mathrm{d}}$ & $29.2 \pm 0.51^{\mathrm{a}, \mathrm{b}}$ \\
\hline
\end{tabular}

Values are mean \pm SEM $(n=6)$. Values are statistically significant at $* \mathrm{P}<0.05$ using one way ANOVA followed by Tukey's test. a: $\mathrm{p}<0.05$ vs negative control $\mathrm{b}: \mathrm{p}<0.05$ vs positive control, $\mathrm{c}$ : $\mathrm{p}<0.005$ vs standard, $\mathrm{d}: \mathrm{p}<0.05$ vs test $1, \mathrm{e}: \mathrm{p}<0.05$ vs test 2

\section{DISCUSSION}

The result of this study revealed that sesame extract accelerated the gastric healing in stress induced ulcer when dosed for a period of 7 days and the rate of healing is comparable to the standard drug pantoprazole.

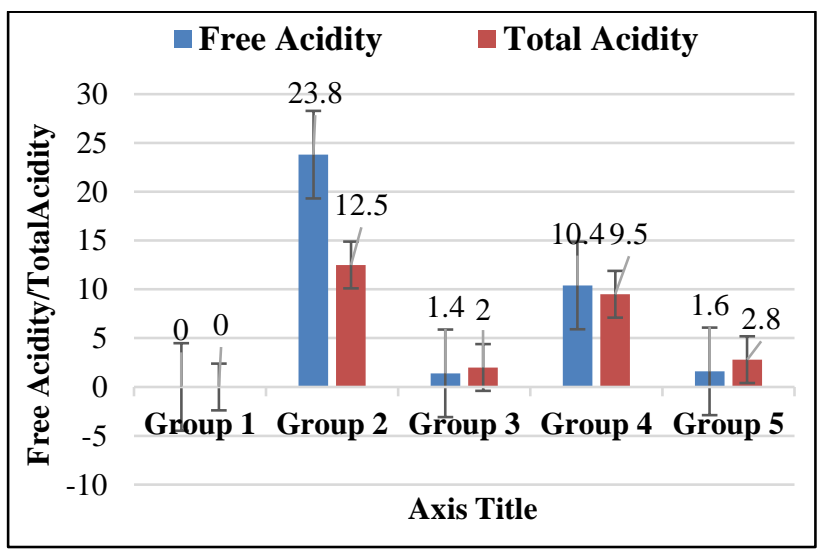

Figure 5: Mean free and total acidity.

The evidence is based on the changes noticed in the gastric mucosa, gastric $\mathrm{pH}$, mucin content, gastric volume, free acidity and total acidity.

The high dose sesame group $(1 \mathrm{mg} / \mathrm{kg})$ showed the significant reduction in the gastric mucosal damage when compared with the control and standard pantoprazole group $(30 \mathrm{mg} / \mathrm{kg})$. All other parameters like mucin content, gastric $\mathrm{pH}$, volume, free and total acidity were comparable.

Group 3 (pantoprazole 30mg/kg) and group 4 low dose sesame $90.5 \mathrm{mg} / \mathrm{kg}$ ) showed the significant difference in all the parameters when compared with group I and II.

These ulcers occur following severe stress. The causes are as follows: Psychological stress, physiological stress which occurs in conditions like shock, severe trauma, extensive burn (Curling's ulcer), septicaemia, cushing's ulcer. $^{4}$

The pathology of the stress ulcer is not clear, the possible hypotheses for genesis of stress ulcers is Ischaemic hypoxic injury to the mucosal cells and depletion of the gastric mucus barrier rendering the mucosa susceptible to attack by acid-peptic secretions. ${ }^{4}$

In the present study the ulcer induction was done using restraint cage and placing the rats in cold ventilated freezer for 2 hours. Edward et al, studied the Synergism between cold and restraint for rapid production of stress ulcers in rats and they observed that restraint and exposure to cold acted synergistically to produce gastric ulcers. ${ }^{5}$

Sesame (Sesamum indicum) belongs to family Pedaliaceae with the chemical compositions of lignans, sesamolin, sesamin, pinoresinol and lariciresinol. Sesamol (SES), is a component of traditional health food in various Asian countries. It protects against atherosclerosis, hypertension, and aging. It has also been explored for wound healing, 
antioxidant, anti-inflammatory, and free radical scavenging activity. ${ }^{6}$

Sesamum indicum contains phenols, flavonoids, anthocyanins, cyanogenic glycosides, polyacetylene alkaloids and peptides, the plant also contains vitamins like riboflavin, nicotinic acid tocopherol, pantothenic acid, thiamine, niacin, and trace amount of ascorbic acid. ${ }^{7}$

Several flavonoids prevent gastric mucosal lesions produced by various models of experimental ulcer and protect the gastric mucosa against various necrotic agents.

They are the most important plant constituents associated with anti-ulcer activity and also stabilize membranes and this may be the mechanism by which they inhibit ulcer induction. ${ }^{8}$

Sesame was shown to have the anti-ulcer and antisecretory properties of the hexane extract of Sesamum indicum several studies have been conducted on extract of sesame on ethanol, NSAID's and water immersion induced ulcer model and have been observed positive results. ${ }^{9}$

In the present study it is observed that the extract of sesame attenuated the gastric mucosal damage by its antioxidant and free radical scavenging property, so this model (cold restraint) can confirm the gastro-protective property.

\section{CONCLUSION}

Although the high dose sesame $(1 \mathrm{mg} / \mathrm{kg})$ group showed significant gastric protection against ulcer induced by cold restraint method. However no clear inference can be drawn at this stage and hence we consider the work for further extensive research.

\section{ACKNOWLEDGEMENTS}

Authors would like to thank Dr. Niraj Jain, Dr. Alok Pandey, for his support during study.

Funding: No funding sources

Conflict of interest: None declared

Ethical approval: The study was approved by the Institutional Animal Ethics Committee (IAEC/KMC/13/2016)

\section{REFERENCES}

1. Adinortey MB, Ansah C, Galyuon I, Nyarko A. In vivo models used for evaluation of potential antigastroduodenal ulcer agents. Ulcers. 2013 Jun $25 ; 2013$.

2. Zohary D, Hopf M. Domestication of Plants in the Old World: The Origin and Spread of Cultivated Plants in West Asia, Europe, and the Nile Valley Oxford University Press; 2000. ISBN 0-19-850356-3 Retrieved 2012-06-17.

3. Rao CM, Ramesh KU, Bairy KL, Kulkarni OR. Evaluation of Gastroprotective Effect of Terminalia chebula Fruit Extract in Stress-Induced Peptic Ulcers in Wistar Rats. Indian drugs. 1990:28;64-7.

4. Grichar WJ, Dotray PA, Langham DR. Sesame (Sesamum indicum L.) growth and yield as influenced by preemergence herbicides. Inte $\mathrm{J}$ of Agrono. 2012;2012.

5. Edward, Senaya ND, Robert J, Levin. Synergism Betweem Cold and Restraint for Rapid Production of Stress Ulcers in Rats. P.S.E.B.M.; 1967:124.

6. Kondamudi PK, Kovelamudi H, Mathew G, Nayak PG, Rao MC, Shenoy RR. Investigation of sesamol on myeloperoxidase and colon morphology in acetic acid-induced inflammatory bowel disorder in albino rats. The Scientific World Journal. 2014;2014.

7. Chakraborthy GS, Sharma G, Kaushik KN. Sesamum indicum: a review. J herb med toxicol. 2008;2(2):159.

8. Martin MJ, Motilva V, de la Lastra ÓN, Alarc C. Quercetin and naringenin; effects on ulcer formation and gastric secretion in rats. Phytotherapy Research. 1993 Mar 1;7(2):150-3.

9. Kuo PC, Lin MC, Chen GF, Yiu TJ, Tien JT. Identification of methanol-soluble compounds in sesame and evaluation of antioxidant potential of its lignans. J Agric Food Chem. 2011;59(7):3214-9.

Cite this article as: Sori RK, Balaji $\mathrm{O}$, Adiga $\mathrm{S}$, Thomas H. Evaluation of the antipeptic ulcer activity of the seed extract of sesame (Sesamum indicum) in stress induced peptic ulcers in rats. Int J Basic Clin Pharmacol 2018;7:1131-5. 